\title{
Dynamics of Anthropogenic Desertification of the European Desert on the Example of Russian Precaspian Region
}

\author{
Victoria Georgievna Lazareva ${ }^{1 *}$, Valentina Aleksandrovna Bananova ${ }^{2}$ \\ ${ }^{1}$ Ukhta state technical University, Pervomayskaya St., 13, Ukhta, 169300, Komi Republic, Russia \\ ${ }^{2}$ Kalmyk state University, Pushkin St., 11, Elista, Republic of Kalmykia, 358000, Russia \\ *Corresponding authorE-mail: lazareva.v.g@mail.ru
}

\begin{abstract}
This article represents the results of multi-annual researches of desertification processes in droughty part of Europe - Russian Caspian Basin. Authors consider desertification as unification which leads to degradation of all components of arid ecosystems. It has been determined, that ecological-dynamic series of vegetational communities have the largest indicative value on quaternary terraces of Caspian Basin. They allow to trace the degradation sequence, to allocate the evaluation criteria and stages of desertification. Modern region vegetation is a result of cattle pasture and water management. It has been established that the vegetation of Late Khvalynian terrace on loamy soils is the most resistant to processes of degradation. The most vulnerable is young New Caspian. Cartographic materials confirm convertibility of desertification processes in semi-arid zone of European continent in response to natural-anthropogenic factors.
\end{abstract}

Keywords: Anthropogenic succession; Biological conception; Desertification; Indicators; Pasture degradation; Quatenary terraces; Unification; Vegetation;

\section{Introduction}

The problem of desertification in arid zones remains one of the most urgent both in Russia and abroad. The UN convention defines this process as "soil degradation in droughty, half droughty and dry subhumid areas. The process is a result of various factors, including climate change and human activity" [1]. Among modern works devoted to desertification, a series of monographies can be related to this problem [2, 3, 4, 5, 6, 7].

Regional researches make great importance in the struggle of desertification. Arid landscapes are situated in the South-East of Russia and confined to the North-West part of Prikaspijskaya lowland in the European continent. The scientists of Kalmyk State University have developed a biological conception, according to which vegetation is a result of different degradation processes. These processes include excessive pasture, changes of climax communities zone to short-term derivatives, changes of productivity and quality of pasturable forage. The decrease of antropogenic factor and humid climate influenced the restoration of vegetable covering. Consequently, desertification in the Russian Caspian Basin is related to convertible cyclic processes [8, $9,10,11,12]$.

The purpose of this work is to study the dynamic features of anthropogenic desertification in Russian Caspian Basin.

\section{Materials and Methods of Researches}

The collection of field material was implemented by routing and semi-permanent methods during expeditions of the botany faculty of Kalmyk State University $(1989,1994-2015)$ and the faculty of the biogeography of Lomonosov Moscow State University (1990-
1993). During quatenary period three terraces were generated (Early Khvalynian, Late Khvalynian, New Caspian) on the territory of Russian Caspian Basin. They appeared as a result of oscillations of the Caspian Sea level. Observations were led on 12 grounds located on Late Khvalynian and New Caspian terraces, covering area is from 16 to $20 \mathrm{ha}$. Conducted analysis of anthropogenic vegetation is based on 547 geobotanical descriptions. Examinated rules of formation of deteriorated ecosystems were found out with use of techniques developed by FAO / UNEP [13] and Turkmenistan AH deserts studying Institute [14]. Not just separate types of plants were indicators of desertification types but communities, in which they dominate [10, 15, 16]. Anthropogenic factors according to their origin are divided into two groups: biogenic and technical. The first includes consequences caused by pasture digression. The second one is technical, and it includes construction and operation of irrigation systems, plowing and etc. The data of remote sounding were processed in GIS-program MapInfo 6.0 and were implemented for monitoring and mapping of desertification. Transformation of space pictures was processed in the program ArcGIS 9.3.

Space images Landsat TM / ETM were used for definition of the impact of desertification degree. The method of colour combinations 3, 2, 1 (natural colours) and 4, 3, 2 [17] was the most efficient during decoding of vegetation cover in Russian Caspian Basin. Use of ecologist-dynamic method profiling allowed to define anthropogenic succession while practical use of overgrazing and water irrigation on quatenary terrace [15].

\section{Results of Researches}

Desertification is a result of many factors. Among these factors the climate and anthropogenic impacts are the most important. 
They are represented the most clearly by cartographic materials. These maps are developed by the scientists of Kalmyk and St. Petersburg State universities and RAS institute. The maps show anthropogenic dynamics of Russian Caspian Basin, Kalmyk Republic in general. The $70 \mathrm{~s}$ and $80 \mathrm{~s}$ of XX century are characterised as the period of the largest anthropogenic load in the conditions of arid climatic cycle. Strong and very strong stages of desertification prevailed in vegetation cover, taking 52,9\%, including $10 \%$ (770 thousand hectare) of blowouts. Only $15 \%$ of cover were related to the weak stage, including $12,8 \%$ of fields from the whole territory of Kalmyk republic. Condition of regional landscapes corresponded to the zone of ecological disaster [18]. The period of 1990-2007 can be remarked as a period of the least anthropogenic load and increase of climate humidity. The positive impact was brought to vegetation cover, the weak stage of degradation was dominated with $66,3 \%$, strong and very strong took only $13,2 \%$. The area of open sand decreased up to $1,63 \%$ (126 thousand ha). Consequently, at that time, the vegetation cover experienced redesertification process $[19,20]$. Currently, in the region a hug pressure is put on pasture and as a result, new seats of deflation emerge [22].

Features of anthropogenic degradation of vegetation cover were studied on quaternary terraces: New Caspian and Late Khvalynian, which have various granulometric composition of soils. New Caspian terrace is traced on Western coast of Caspian Sea with the marks of -21 to $-27 \mathrm{~m}$ above sea level. Age of her continental development dates to approximately $6-8$ thousand years [21]. The terrace is located on seaside sandy-saline plain, where vegetation cover of zone is presented by hemipsammophytic and psammophytic variants of gramineous low bush (Artemisia lerchiana, Stipa sareptana, Festuca valesiaca, Agropyron fragile, Poa bulbosa) deserts.

Late Khvalynian terrace takes the Central and Southern part of Russian Caspian Basin. The age of its continental development is 9-11 thousand years, absolute mark varies from -5 to $+20 \mathrm{~m}$ above sea level [21]. Vegetation cover is dominated by the complexe North Precaspian suffruticulose and gramineoussuffruticulose deserts (Artemisia lerchiana, A. pauciflora, Kochia prostrata) which have been used for pastures since the long time. At present time growth of the cattle livestock threatens to its total extinction or replacement by short-term derivative (ephemerous and annual) communities. In accordance with the increase of pasture digression, the transformation of ordinary component (annual cenosis) into its dominant (or vice versa) takes place in vegetation cover. This process was named as "rearrangement unification". Penetration of new types and taking by them leading position in the community was named as "implementation unification" $[10,22]$. As a result, serial derivative communities appear in the vegetation cover alternating each other not only in time, but also in the space. These communities can be used as indicators. Series formed by these communities are ecological as they are situated progressively according to increase or decrease of pasture load in the seats of digression or out of them [22].

At present time, practically all vegetation cover of the region has been changed and it is not uniform. It consists of communities on various stages of degradation and also of the grassland of different age. Consequently, modern vegetation cover has no fixed structure, nor determined laws in distribution of its components [22, 24]. Therefore, we can observe smooth exogenic succession of regressive type in the range plant cover.

The space pictures were used during development of schematic maps of "Modern anthropogenic desertification in Northwest Caspian Basin" and "The strategies of struggle with desertification". The "GIS » draft model of maps was created in the program MapInfo Professional 6.0. Vector layers of « GIS » model include information of: underground cover, vegetation communities, crop yield, classes of pasture digression. Such elements, as Eastern slope of Ergeni upland, lakes, channels, villages and folds are clearly visible on the space images. But at the same time, it is impossible to distinguish steppe and desolate vegetation on different stages of degradation. Due to that, the maps are based on materials of dispatch researches. These materials allow to define the type of vegetation, level of degradation and methods of restitution on quaternary terraces which are composed of various soil textures [23, 24].

\section{Pasture Digression}

The research was conducted in South West part of Late Khvalynian terrace on the landfill "Mekletinskij" (X - 45.243477; $\mathrm{Y}$ - 46.102632), located in zones of gramineous sub-shrub deserts with (Artemisia lerchiana, A. pauciflora, Poa bulbosa, Stipa lessingiana, $S$. sareptana, Festuca valesiaca, Agropyron desertorum). They form complexes with (Artemisia pauciflora) and (Artemisia taurica) communities on loamy solonized soils. Pasture degradation stages were observed in different time periods: with the lowest anthropogenic loam level (1990-2000) and the highest one $(1989,2015)$.

In $70-80$ s the proving ground herbage was used intensively for pasture and as a result strong and very strong classes of degradation were observed. The herbage was mostly represented by annual plants (Climacoptera brachiata, Petrosimonia oppositifolia) and ephemeroid (Poa bulbosa). Due to the decrease of pasture cattle, the composition of herbage had changed: communities from (Climacoptera brachiata, Petrosimonia oppositifolia, Artemisia pauciflora) were transformed to (Artemisia pauciflora, Climacoptera brachiata, Petrosimonia oppositifolia), what corresponded to the moderate stage of degradation. The same process was observed in (Poa bulbosa, Artemisia lerchiana, Petrosimonia oppositifolia) plant communities.

In the beginning of 21 century weather conditions were characterised as rather humid, therefore the range plant cover had restorative succession. The presence of dwarf shrubs highly increased in herbage: Kochia prostrata, Tanacetum achilleifolium, Artemisia lerchiana, as well as haloxerophile annual plants (Climacoptera brachiata, Petrosimonia oppositifolia) appeared. Besides the appearance of halophytic shrubs (Halocnemum strobilaceum) in the composition of (Artemisia pauciflora). (Halocnemum strobilaceum) influenced the increase of humidity and salification in potting soil. Sebsequently this process had intensified. Halomesophytes such as (Aeluropus littoralis, Artemisia santonica) emerged in the composition of plant communities.

By 2015 Halocnemum strobilaceum became subdominate in (Artemisia pauciflora) cenosis, and determinant in (Artemisia lerchiana) community. In the soils with domination of (Artemisia pauciflora, Halocnemum strobilaceum) communities, dissolved solids increased from $0,718 \%$ in 1995 to $1,180 \%$ in 2015 . This is the result of exceed number of cattle on the one side and the rising of Caspian Sea level on the other. Sheeps also impacted top layers of loamy soils by hooves. During transgression and stabilization and despite significant distance from Late Khvalynian terrace, the sea also faciliates the rise of the salty ground waters. Consequently, succession on loamy soils increases hygrohalophilic process of vegetation communities. They are observed not only in lowlands, but also on plains with (Poa bulbosa, Artemisia lerchiana) and (Artemisia pauciflora) herbage. At present time, as a result overgazing, dwarf shrubs continue to decrease, at the same time the impact of ephemers, ephemeroids and annual plants has increased [24].

Researches on brown sabulous and sandy soils were led on the landfill "Tsagan-Aman", (GPS: X -46.713785; Y - 47.602099), located in the northeast part of Late Khvalynian terrace. The testing area was on the sand massif "Sungrub" of the right side of Volga river. Zonal vegetation is represented by (Artemisia lerchiana, Agropyron fragile, Stipa sareptana) deserts, which in $70-80$ s XX century had a very strong ephemeral digression. This digression was followed by creation of hilly sands with rare 
(Leymus racemosus) sods. Decrease of pasture load in the beginning of XXI century helped forward restoration of infringed communities. Studying the demutational process became the purpose of our researches. The main ecological factor was absence of cattle pasturage for more than 30 years [11, 24].

However, by the beginning of XXI century the situation had changed, active demutation took place, during which blady grass communities had been changed by (Artemisia lerchiana, Stipa sareptana, Leymus racemosus). Common plant cover, species composition and productivity inscreased (45\%: 17 species: 16,5 centner / ha). Single samples of Leymus racemosus were considered as relics of a very strong class of desertification during the last century. Common species of compared years were psammophytes: Leymus racemosus, Festuca beckeri, Koeleria glauca. It is necessary to mention, that restoration process of vegetation cover of sandy massif on different relief had its features. At the beginning of researches in small-sized lowlands (Leymus ramosus, Stipa capillata, Artemisia lerchiana) communities were registered. In thirty years communities of (Artemisia austriaca, Leymus ramosus, Stipa capillata, Artemisia lerchiana) with psammophytes (Syrenia siliculosa, Agriophyllum squarrosum, Agropyron fragil) prevailed. The common plant cover increased from $20-25 \%$ to $55 \%$.

On the top of sandy massif in 70s (Artemisia lerchiana, Bromus japonicus, Syrenia siliculosa) communities with participation of Agropyron fragile augmented. In 2015 the herbage containted (Agropyron fragile, Artemisia lerchiana, Leymus racemosus). The common plant cover increased from $10 \%$ to $45 \%$. Grasses (Leymus racemosus, Agropyron fragile, Festuca valesiaca, Stipa sareptana) made $67,9 \%$ from hay crop weight, dwarf shrubs (Artemisia lerchiana, A. arenaria, Kochia prostrata) - 30,5\%, motley grasses (Syrenia siliculosa, Gypsophyla muralis) - 1,6\% During compared years common communites were presented by (Leymus racemosus, Artemisia lerchiana, A. arenaria, Agropyron fragile, Kochia prostrata) [11,24].

In the beginning of researches (1972) the communities of meadow-steppe type with presence of xeromesophytes dominated in inter barkhan lowlands: Agropyron pectinatum, Galium verum, Artemisia austriaca, Elytrigia repens. Floristic composition included only 6-11 types in the common plant cover which is 20$25 \%$. Psammophytes were practically missing. We met occasionally Leymus racemosus, Agropyron fragile, Festuca beckeri, Stipa sareptana. By the beginning of 21 century herbage became more uniform and more generated. Floristic diverse types included 13-15 types. The common plant cover was taking from 50 to $90 \%$.

Consequently, Russian Caspian Basin, one of the most arid and dynamical regions of European continent, reflects both natural, and anthropogenic impacts. The most important factor is climate: arid cycle helps xerophytization process; more humid climate impacts the most important process - mesoxerophytization of species composition of vegetative communities. Regressive type succession was observed under high anthropogenic influence, and demutation under low anthropogenic influence which proves convertibility of regional desertification $[19,20]$. In our opinion, consequences of pasturable degression on loamy soils make oscillations of Caspian Sea level more significant, in spite of far terrace distance $[21,24]$.

\section{Anthropogenous Dynamics of Vegetation in Canal Zone of Quaternary Terraces}

Speaking about the forms of technical desertification in Caspian Basin, the channels constructed in ground bed make the most negative influence to natural-territorial complexes (NTC). In this work we studied the improvement of hydro irrigation system for the vegetation of Late Kvalynian and New Caspian terraces situated on sandy and loamy soils.
Proving ground "Preergeninskij" is located in Western part of Late Khvalynian terrace which forms a narrow band stretching along the foot of Ergeni's highness (GPS: X - 45.243477 Y - 46.102632) From geomorphological point of view, it is a gently rolling plain inclining to the South-East. Its absolute height varies from +8 to $8 \mathrm{~m}$. The typical feature of the relief is wide circulation of limanshaped downwards and small salty lakes which dry up in the summer. Many of them are connected with the beams of Ergeni. A small flow increases the mineralization of ground waters (from 1 to $100 \mathrm{~g} / 1$ and more). The type of salt accumulation in such waters is chloride-sulphatic. The depth in limans is about $2-5 \mathrm{~m}$ and in inter liman spaces is $15-20 \mathrm{~m}$. Soils are characterised by high residual salinity. Priergeninskaja hollow is considered by many scientists as a contact zone of waterside land of Early and Late Khavlynian seas $[24,25]$.

For the first time the area was surveyed in 1977 before construction of irrigation systems. Proving ground is located in Artemisia lerchiana deserts, herbage is composed of four - five parts: with (Artemisia pauciflora, Camphorosma monspeliaca) on crust, small-sized alkali soil, and (Stipa capilláta, Artemisia lerchiana, Agropyron desertorum) communities on brown desolate-steppe soils. The slopes were presented by (Artemisia lerchiana, Camphorosma monspeliaca, Salsola) herbage. The vegetation composition was dominated by (Artemisia santonica, Aeluropus littoralis) herbs on meadow-chestnut soil of lowlands. The solid varied from 0,351 to $0,543 \%$, with chloride type of salting. Ground waters were located at a depth of more than $6 \mathrm{~m}$ and practically unaffected vegetation. In the beginning of 80 s the construction of Chernozemelskaya water facilities, channels reached the central part of the hollow Priergeninskaya. The discharged collector "Chernozemel'skij" was passing close to experimental ground [8].

Filtration of channel water caused flooding and lateral salting of adjoining territories. The most significant changes took place in the area of $0-3$ meters. The zone of dwarf shrubs communities was replaced by the zone of hydromorphic halophytic belt made from (Phragmites australis, Salicornia perennans) communities, which transformed in 10 years into (Salicornia perennans, Aster tripolium) community. Species composition almost entirely changed (index of floristic similarity was $14 \%$ ). The halophytic (Aeluropus littoralis, Elytrígia répens, Artemisia santonica) meadow zone was replaced in some cases by halophytic (Halocnemum strobilaceum) communities and by (Puccinela distans) with admixture (P. dolicholepis) grass in others. These changes are caused by increase of degree and change of salting type of soils from $1,1 \%$ in 1987 to $5,3 \%$ in 2015 . Also, the change of sulphatic-chloride type of salting to chloride and rise of ground waters on $0,1 \mathrm{~m}$ made its influence $[10,12,22]$.

The researches on loamy soils of Late Khvalynian plain were conducted also on Yashkul'skij channel near village Gashun. The amount of toxic salts on the belt of 0-20 m from waterline made $60 \%$ from common quantity. The presence of Salicornia perennans in reed thickets was the indicator of chloride-natrium salting in ground waters close to the surface. The herbage became Salicornia perennans monodominant. The fact of situating on external embankment at distance of 20-25 m away from channel shows the maximum of soil salinity. Sodium chlorides are subject to disperse to $40-50 \mathrm{~m}$ from the site. The most intense concentration of less mobile - sulphate was observed. Such types, as Salicornia perennans, Halimione verrucifera, etc. develop in chlorides accumulation area, and Frankenia hirsuta, Petrosimonia oppositifolia present in the soils with prevalence of sulphate salts. In the band of $50-130 \mathrm{~m}$ you can find (Puccinellia distans, Halimione verrucifera) meadows. In (Artemisia pauciflora, Anabasis aphylla) communities salting of rooting layer is absent. The similar sequence of vegetation communities and soils salting is traced at the dam of Tchograjskij reservoir $[12,26]$.

Studying the influence of water management on New Caspian terrace was also conducted by method of ecological-dynamic profiling, with length of profiles on 1-3 kms. Researches were 
held on experimental grounds "Rakushi”, "Lagan"”, "Dzhalykovo", territory where the channels of Caspian water irrigation system pass through. Results of researches showed that influence of channel made appear a complexity on vegetatation cover. On the base of gently rolling (Artemisia lerchiana, Anisanta tectorum, Lapula echinata, Alyssum turkestanicum) plain, appearance of (Agriophyllum squarrosum), (Achillea micrantha) with Leymus racemosus, also Artemisia arenaria, Koeleria glauca, in microlowlands belts - (Achillea micrantha, Artemisia arenaria Salsola australis, Syrenia siliculosa, Descurainia Sophia) plant formation with single sods Festuca beckeri, Koeleria glauca, Corispermum aralo-caspicum, Agriophyllum arenarium can be observed. The surface of these formations showed the presence of dark dust sand with thickness level of 5-15 sms. This level becomes theacker according to distance from the channel and on distance of 400-600 m disappears entirely. Communities of (Achillea micrantha, Agriophyllum squarrosum) on dark sands gradually penetrates to the plain with Aeolian erodes.

Therefore, while studying the influence of water supply channels, the territory covers the New Caspian terrace and spreads on sandy soils and soil-forming rocks containing the layers of easy loams. On the landfill "Lagan"', in the zone of channel influence, the (Artemisia lerchiana, Agropyron fragile) as well as Phragmites australis, Glycyrrhiza glabra, Alhagi pseudalhagi are the indicators of lateral filtration in the hemipsammophytic desert.

Frequently met Salvinia natans groups creat stagnation in the channelfoot. They detain sand which fells from the boards and it helps the development of reed sprouts, (Phragmites australis), (Typha latifolia) and (Utricularia vulgaris). Several meters further the channel practically ceases to function.

Consequently, stability of different types of the vegetation regarding the factors causing degradation is rather various According to the held researches we can conclude that, in spite of pasturable degression scale, technogenesis is the most significant factor, as degradations take place not only in undergroundvegetation cover, but also in soil-formating rocks [22].

\section{The Strategy of Improvement and Rational Use of Vegetation Cover of Russian Caspian Basin}

This is a text of acknowledgements. Do not forget people who have assisted you on your work. Do not exaggerate with thanks. If your work has been paid by a Grant, mention the Grant name and number here.

In order to rehabilitate the phytocenotic diversity of natural lands in the region, the maps "Danger of desertification of Southern federal area" [26], a map-scheme "The strategy of vegetation cover restoration of pastures in Northwest Caspian Basin" were developed M 1:1000 $000[22,24]$. Their analysis showed that at present time in the zone of Russian Caspian Basin such methods as rational use of surface $(69,6 \%)$, root improvement, agro-forest amelioration (30,1\%) (Table.1) must be applied to restore degraded pastures.

Table 1: Restauration strategy of degraded pastures of Northwest Caspian Basin

\begin{tabular}{|c|c|c|c|c|}
\hline \multirow{2}{*}{$\begin{array}{c}\text { Methodes of } \\
\text { succession of } \\
\text { degraded pastures }\end{array}$} & $\begin{array}{c}\text { Qarly } \\
\text { Khvalynian }\end{array}$ & $\begin{array}{c}\text { Late } \\
\text { Khvalynian }\end{array}$ & $\begin{array}{c}\text { New } \\
\text { Caspian }\end{array}$ & Total \\
\cline { 2 - 5 } & \multicolumn{4}{|c|}{ I. Rational use of surface } \\
\hline $\begin{array}{c}\text { 1. Decrease of pasture } \\
\text { loam on 25\%+ } \\
\text { pasture rotation }\end{array}$ & 9,9 & 10,2 & 0,7 & 8,4 \\
\hline $\begin{array}{c}\text { 2. Decrease of pasture } \\
\text { loam on 50\%+ } \\
\text { pasture rotation }\end{array}$ & 25,5 & 17,6 & 22,7 & 21,2 \\
\hline $\begin{array}{c}\text { 3. Land set-aside on 3- } \\
\text { 5 years }\end{array}$ & 39,9 & 43,3 & 15,4 & 37,6 \\
\hline 4. Land set-aside on 5- & 1,8 & 0,7 & 12,8 & 2,7 \\
\hline
\end{tabular}

\begin{tabular}{|c|c|c|c|c|}
\hline \multicolumn{5}{|l|}{10 years and more } \\
\hline TOTAL: & 77,1 & 71,8 & 51,6 & 69,6 \\
\hline \multicolumn{5}{|c|}{ II. Superficial enhancement } \\
\hline $\begin{array}{l}\text { 1.Planting, grass } \\
\text { underseeding, forest } \\
\text { transplanting, tree and } \\
\text { shrub planting }\end{array}$ & & 9,1 & 30,1 & 6,0 \\
\hline 2. Furtilizer dressing & 4,4 & 1,4 & 1,3 & 2,3 \\
\hline $\begin{array}{l}\text { 3. Deep flood } \\
\text { irrigation }\end{array}$ & 5,2 & 1,6 & & 2,5 \\
\hline TOTAL: & 9,6 & 12,1 & 31,4 & 10,8 \\
\hline \multicolumn{5}{|c|}{ III. Amelioration } \\
\hline $\begin{array}{l}\text { 1.Planting on loamy } \\
\text { soils (rotation pasture) }\end{array}$ & 3,2 & 1,8 & 2,0 & 2,2 \\
\hline 2. Drainage & 1,7 & 3,0 & & 1,9 \\
\hline 3. Replanting of sods & 1,8 & 2,6 & & 1,6 \\
\hline TOTAL: & 6,7 & 7,4 & 2,0 & 5,7 \\
\hline \multicolumn{5}{|c|}{ IV. Agro-forest amelioration } \\
\hline $\begin{array}{l}\text { 1. Plant seeding and } \\
\text { planting of tree-shrubs } \\
\text { on sandy and sabulous } \\
\text { soils }\end{array}$ & & 2,8 & 15,0 & 8,5 \\
\hline $\begin{array}{l}\text { 2. Tree and shrubs } \\
\text { planting around } \\
\text { population centres and } \\
\text { beam slopes on loamy } \\
\text { soils }\end{array}$ & 6,6 & 5,9 & & 5,1 \\
\hline TOTAL: & 6,6 & 8,7 & 15,0 & 13,6 \\
\hline TOTAL $\%$ & 100 & 100 & 100 & 100 \\
\hline
\end{tabular}

It is necessary: to reduce the pasture load by decreasing the cattle on $25-50 \%$, the surface on $29,6 \%$, with exception of land set-aside on 3-5 years $-37,6 \%$ applying a rational approach. It is important to seed psammophytic grass and plant bushes on the brown soils surface of $19,6 \%$. To our opinion the drainage is possible mainly on rice estuaries of Bolshoi Tsarin and canal areas of Chernozemel'skaya, Caspian and Sarpinskaya irrigation systems. The rational use method is applicable regarding to all Ancient Caspian terraces, (77,1: 71,8: 51,6\%), superficial enhancement and agro-forest amelioration are the most suitable methods for New Caspian terrace (31,4: 15,0\%) and amelioration strategy must be applied on Late Khvalynian terrace (7,4: 8,7\%).

\section{Conclusions}

1. On European continent Russian Caspian Basin is the only arid region. This is a transitional zone between steppe and desert and is characterised by high exposure to the desertification processes.

2. Developed biological conception and methods of research define vegetation and ecological-dynamic series as indicators of anthropogenic desertification process. The vegetation of more ancient territories is the most resistant to degradation particularly on loamy soils of Late Khvalynian terrace, the most vulnerable is the vegetation on sandy and sabulous soils of young New Caspian terrace.

3. The mechanism of pasture degression and water management has been determined. The change of vegetation community dominants on determinants was named as "rearrangement unification". Penetration and acquisition of leading position in the community of new types was named as "implementation unification".

4. In the zone of Northwest Caspian Basin convertibility of desertification process has been observed. During decrease of anthropogenic factor, the restitution succession concerning regeneration of root vegetable communities was noticed. However ecological instability arises as soon as antropogenic factors increase.

5. For restoration and preservation of vegetation cover it is important to apply all kind of necessary methods such as rational use, superficial improvement and amelioration, agro-forest amelioration, monitoring supervision with use of cartographic materials and creation of new natural areas. 


\section{References}

[1] UN (1994), United Nations Convention to combat desertification in those countries experiencing serious drought and desertification, particularly in Africa. Geneva, Switzerland.

[2] Arnalds O \& Archer S (2000), Rangeland desertification. SpringerScience+Business Media.

[3] Cathy L \& Schaaf T (2006), The Future of Drylands: International Scientific Conference on Desertification and Drylands Research. Tunis, Tunisia, 19-21 June, Springer.

[4] Sivakumar MVK \& Ndiangui N (2007), Climate and Land Degradation: Environmental Science and Engineering Subseries: Environmental Science. Springer.

[5] Zdruli P, Pagliai M, Kapur S \& Faz Cano A (2010), Land Degradation and desertification: Assessment, Mitigation and Remediation. Springer.

[6] Vaganov EA, Zolotokrylin AN \& Ptchelkin AV (2008), Evaluative report about climate change and its consequences on the territory of Russian Federation. Changes of natural and economic systems in XX century. Moscow: Russian Meteorological service, 101-124.

[7] Drozdov AV, Zolotokrylin AN, Mandich AF, Bubnova AR, Volkova IN, Vinogradova VV, Golieva AA, Kovda IV, Kuderina TM., Morozova OV, Tertitsky GM, Cherenkova EA, Chichagov VP, Zolotov DV \& Chernykh DV (2009), Desertification of droughty areas of Russia: new aspects of analysis, results, problems. Moscow: Fellowship of scientific issues KMK.

[8] Bananova VA (1986), Methodological regulations for studing the desertification process of arid territories in Kalmyk SSR. Elista: Kalmyk State University.

[9] Neronov VV (1998), Antropogenic steppe formation on desert range land of North-West part of Precaspian lowland. Achievements of modern biology 118(5), 597-612.

[10] Lazareva VG (2003), Botanical diversity of North-West Precaspian area under conditions of Caspian Sea level fluctuation. Elista: Dzhangr.

[11] Lazareva VG \& Bananova VA (2014), Tendencies in variations of botanical diversity under impact of desertification in Republic of Kalmykia. Arid ecosystems 20, 2(59), 87-96.

[12] Lazareva VG, Bananova VA, Kharitonov ChS, Goryaev IA \& Zung NV (2016), Indicator role of vegetation in response to amelioration of arid landscapes of Precaspian area (on example of Republic of Kalmykia). South of Russia: ecology, development 11(3), 151-164.

[13] FAO/UNEP. Provisional methodology for assessment and mapping of desertification. Rome, 1984.

[14] Kharin NG, Netchajeva NM \& Nikolaev VA (1983) Methodological regulations for studing desertification and its mapping system (on example of arid zones of Turkmenistan). Ashkhabad: Ilim.

[15] Viktorov SV, Vostokova EA \& Vishivkin DD (1962), Introduction in indicative geobotanics. Moscow: Moscow State University.

[16] Vinogradov BV (1964), Vegetal indicators and its usage in studying natural resources. Manual for geo, bio, agro and geology faculties of state universities. Moscow: Visshaya Shkola.

[17] Petrov KM, Bananova VA, Lazareva VG, Unagaev AS (2016), Dinamics of desertification process on North-West Precaspian area: physiogeographic and socio-economic aspects (atlasmonography). St. Petersburg: Himizdat.

[18] Bananova VA (1989), Map of antropogeneous desertification of arid territories in Kalmyk SSR. M. I: 500.000. Novotchekassk.: South Federal Institute of agriculture and aero phototopography researches.

[19] Borlikov GM, Kharin NG, Bananova VA \& Tataishi P (2000), Desertification of droughty areas in Precaspian region (Appendix. 3 maps M. 1:1000000 and 1:2500000). Rostov-on-Don: SouthCaucasian Scientific center.

[20] Zolotokrilin AN (2003), Climatic desertification. Moscow: Science.

[21] Ritchagov GI (2014), Khvalynian stage in the histoiry of Caspian Sea. Moscow University news 5(4), 3-10.

[22] Lazareva VG, Bananova VA (2014), Dinamics of antropogenic desertification in arid landscapes of Kalmykia. Elista: Kalmyk State University.

[23] Bananova VA, Saphronova IN, Lazareva VG, Kharitonov ChS \& Zung NV (2016), Vegetation cover of Sarpinskaya lowland in Republic of Kalmykia. Elista: Dzhangr.

[24] Lazareva VG (2018), Transformation of spacial structures of vegetal cover in the South-Western Precaspian zone due to antropogenic impact. News of Samara Scientific Center 20(2),116 123.
[25] Karandeeva MV, Nikolaev VA \& Ritchagov GI (1958), Geomorphology of Western part of Prcaspian lowland. Moscow: Moscow State University.

[26] Lazareva VG., Bananova VA, Tashninova LN \& Sangadzhieva LKh (1988), Vegetation cover of blacklands in Kalmyk SSR. Contribution of young scientists and researchers in socio-economic development of KSSR. Elista: Kalmyk publishment, 75-76. 